\title{
INTEGRAČNÍ KONCEPTY A PROGRAMATIKA POLITICKÝCH STRAN PŘED VOLBAMI DO BUNDESTAGU 2017
}

\section{LUKÁŠ NOVOTNÝ}

\begin{abstract}
Integration Concepts and the Programming of Political Parties before the Election to Bundestag 2017

German elections to the Bundestag last year were significantly affected by the issue of migration. The third position of the Alternative for Germany was achieved particularly due to the party's refusing foreigners in the country. However, all parties were forced to present before the elections their ideas relating to integration; voters expected them to be able to solve recent problems spreading over the country due to the migration crisis. The paper focuses on the characteristics of German politics regarding migrants and attempts to indicate changes in its perception. The main part then concentrates on positions of individual political parties regarding the integration of refugees and their respective integration concepts. The paper outlines the specificity of individual parties and points to differences as well as similarities in their conceptions.
\end{abstract}

Keywords: Germany; migration; migration crisis; integration; assimilation; integration concept

Klíčová slova: Německo; migrace; migrační krize; integrace; asimilace; integrační koncept

DOI: $10.14712 / 23366478.2018 .9$

\section{ÚVOD}

Dozvuky migrační krize byly v Německu skutečně velmi silné. Vyústily např́klad v poměrně silnou podporu Alternativy pro Německo ${ }^{1}$ a v oslabení tzv. tradičních stran, od nichž se voliči částečně odklonily právě proto, že jim nevěrili v jejich schopnosti zajistit vnitřní bezpečnost země. Rozproudily ovšem také např́ílad debatu o tzv. dominantní kultuře (Leitkultur), tedy o tom, co je třeba si chránit a co je třeba, aby ti, kdo se ucházejí o život v Německu, měli o Německu vědět, co by měl respektovat a ctít. ${ }^{2}$ Ostatně proto vydal v dubnu minulého roku spolkový ministr vnitra, Thomas de Maizière „10 tezí o dominantní kultuře“3 (Zehn Thesen zur Leitkutur) a vzniklo i několik dalších podobných dokumentů, jako např́íklad ten od Německé kulturní

1 NOVOTNÝ, L.: Úspěchy Alternative für Deutschland ve třech zemských volbách v Německu. Acta Politologica, 2016, č. 1, s. 40-50.

2 Viz RÖSCH, H.: Deutschunterricht in der Migrationsgesellschaft. Wiesbaden, 2017, s. 45.

3 „Wir sind nicht Burka“: Innenminister will deutsche Leitkultur. Zeit Online. Dostupné z: http://www.zeit .de/politik/deutschland/2017-04/thomas-demaiziere-innenminister-leitkultur/seite-2 [1.2.2018]. 
rady (Deutscher Kulturrat) s názvem ,Jednota v mnohosti. 15 tezí o kulturní integraci a sounáležitosti“"4 (Zusammenhalt in Vielfalt. 15 Thesen zu kultureller Integration und Zusammenhalt). Jak napsal německý ministr vnitra ve svém textu otištěním v „Bild am Sonntag“, svými tezemi, které byly reakcí na znepokojení veřejnosti a na narůstající nedůvěru vůči spolustraničce a kancléřce Angele Merkelové, chtěl vyzvat k diskuzi nad těmito otázkami. ${ }^{5}$ Takové záležitosti, jako podání ruky při pozdravení, nezahalování si obličeje na veřejnosti, všeobecné vzdělání pro všechny, odkaz německých dějin a jejich znalost, „osvícený patriotismus“, svoboda vyznání nebo např́iklad respekt k zvláštním vztahům s Izraelem jsou podle de Maizièra nepodkročitelné atributy německé kultury. ${ }^{6}$

Tyto debaty nejsou v Německu ničím novým. Naopak je nalezneme v různých obdobích a s různou intenzitou podle toho, jak moc se musely řešit problémy s integrací přistěhovalců. ${ }^{7} \mathrm{~A}$ i tato současná diskuze spadá do tohoto určitého kontextu a tím i do nejnovějších dějin německé imigrace a následné integrace. A byla to vždy i témata návratové politiky, smyslu dvojího občanství, integrace do pracovního trhu Německa nebo debata nad hodnotami a ochranou německé identity, která se projevovala s různou intenzitou i v historii země. Způsoby integrace a jednotlivé koncepce byly s ohledem na přítomnost statisíců migrantů pochopitelně předmětem předvolebního boje i v dosud posledních volbách do Spolkového sněmu v záŕí minulého roku.

Mezi klíčové problémy, které se v současných debatách objevují, patří za prvé to, koho chceme integrovat - a koho ne, za druhé jakým způsobem a v jakých oblastech by integrace měla probíhat, za třetí jak dospět k integraci; co se nachází na jejím počátku a co na jejím konci, za čtvrté zda chceme asimilovat, nebo integrovat a za páté jestli chceme, aby se migranti ,jen“ přizpůsobili místní kultuře, nebo je chceme integrovat při zachování některých jejích kulturních a jiných odlišností. Ta druhá cesta je náročnější: vyžaduje totiž určité úsilí i od společnosti, do níž se cizinci mají integrovat. Ostatně mezi póly asimilace-integrace se nacházejí i četné politické debaty. My se zde budeme pokoušet zachytit diskuze nad různými integračními koncepty na př́kladu programových dokumentů v posledních volbách do Spolkového sněmu.

Právě na přístupy jednotlivých politických stran vůči integraci se zaměříme v tomto př́spěvku. Německé integrační právo je totiž sice v zásadě konzervativní a dlouhodobě orientované na nutnost získání pracovního místa, ovšem migrační krize z roku 2015 ho vystavila skutečně silným útokům. Diskuze o tom, jaké právní nástroje akcentují německé politické strany tak byla v předvolební kampani velmi sledovaná. Jde skutečně

4 Zusammenhalt in Vielfalt. 15 Thesen zu kultureller Integration und Zusammenhalt. Deutscher Kulturrat [Online]. Dostupné z: http://kulturelle-integration.de/wp-content/uploads/2017/05/Thesen-Initiative -kulturelle-Integration.pdf [30.1.2018].

5 „Wir sind nicht Burka“: De Maizières Thesen zur Leitkultur. Bild.de [Online]. Dostupné z: http://www .bild.de/news/aktuelles/news/wir-sind-nicht-burka-de-maizieres-thesen-51560496.bild.html [29.1.2018].

6 „Wir sind nicht Burka“. DW.de [Online]. Dostupné z: http://www.dw.com/de/wir-sind-nicht-burka /a-38643741 [29.1.2018].

7 BADE, K. J. - OLTMER, J. (eds.): Zuwanderung und Integration in Niedersachsen seit dem Zweiten Weltkrieg. Osnabrück, 2002; BEER, M.: Zur Integration der Flüchtlinge und Vertriebenen im deutschen Südwesten nach 1945. Ergebnisse der Tagung vom 11. und 12. November 1993 in Tübingen. Sigmaringen, 1994; BENDEL, R.: Wie Fremde zur Heimat wurde. Aspekte der Integration; aus dem Leben bekannter Persönlichkeiten. Stuttgart, 2010; Die Entwicklung Bayerns durch die Integration der Vertriebenen und Flüchtlinge. Mnichov, 1993-2005. 
o klíčové téma, dokonce o téma, na němž se po několik měsíců zadrhla vyjednávání o vládní koalici.

\section{INTEGRACE - NÁVRATOVÁ POLITIKA - DVOJÍ OBČANSTVÍ}

Německo zažilo několik migračních vln. ${ }^{8}$ Tu první tvořili vysídlenci z řad německých menšin v zemích střední a východní Evropy. K nim se muselo přistupovat proto jinak: byli to totiž etničtí Němci, navíc jejich vyhoštění nebo návratová politika fakticky nebyly možné. Naopak jiný byl př́stup k tzv. gastarbajtrům, kteří do země přicházeli od roku 1955. ${ }^{9}$ Jednalo se o pracovní migraci, která proto musela být regulovaná. Ostatně v roce 1974 byl vyhlášen zákaz dalšího přijímání těchto migrantů. Tím se však migrace nezastavila, proto na ní bylo třeba reagovat i legislativně. Spolkové vlády CDU/CSU a FDP následně vypracovaly v 70. letech poziční dokument ,Zásady začleňování zahraničních pracovníkư“, kdy nejen ze samotných zásad, ale i z názvu tohoto dokumentu plyne, že cílem byla skutečně prioritně integrace do pracovního trhu. Zejména následné sestěhovávání rodin vyvolalo také četné společenské polemiky. Na straně jedné stáli konzervativci s jejich představami ,pouhého“ politicko-administrativního začlenění do společnosti, na straně druhé liberálové, kterým šlo o širší zrovnoprávnění; právní, ale i kulturní. Každopádně v roce 1968 vznikl úřad Zmocněnce spolkové vlády pro otázky cizinců, který vedl Heinz Kühn. ${ }^{10}$

Tento úřad získával postupně na významu. Když ovšem v roce 1982 vznikala první Kohlova koalice, složená z CDU/CSU a FDP, ztotožnila se s názorem, že „Spolková republika Německo není žádnou přistěhovaleckou zemí". ${ }^{11}$ Pokud se již tehdyobjevovaly některé integrační nástroje jako jazykové či jiné kurzy, pak se vše konalo fakticky pouze s ohledem na integraci do pracovního trhu.

Současně s tím se činily kroky, podporující návrat těchto gastarbajtrů. Stimulovaly to zejména události ve světě; druhá ropná krize, ale také hospodářská recese v SRN z roku 1982, díky níž se zvýšila míra nezaměstnanosti z 3,8 procent v roce 1980 na 9,1 $\mathrm{v}$ roce 1983 . Nezaměstnaných mezi cizinci bylo dokonce 15 procent. ${ }^{12} \mathrm{~V}$ roce 1983 se

8 BADE, K. J. - OLTMER, J.: Normalfall Migration. Bonn, 2004, s. 127-132.

9 KNORTZ, H.: Diplomatische Tauschgeschäfte. Gastarbeiter in der wetdeutschen Diplomatie und Beschäftigungspolitik 1953-1973. Kolín nad Rýnem, 2008, s. 157.

10 Heinz Kühn byl v integrační politice SRN významnou osobností. Zkušenosti měl coby ministerský předseda spolkové země Severní Porýní-Vestfálsko a hned rok poté, co nastoupil na pozici vládního zmocněnce, tak publikoval text, který je dnes známy jako Kühnovo memorandum. Je to apel na politiky v tom smyslu, aby přestali na cizince pohlížet jako na gastarbajtry. Konstatuje zde, že většina z nich se zde usadila a hodlá usadit a že to je v rozporu s tezí o tom, že Německo není zemí pro přistěhovalce. To byly velmi novátorské teze, které šly proti dosavadní představě o „dočasné integraci“. V memorandu doslova stojí, že politika má mít sociální odpovědnost za ty osoby, které většinově žijí v Německu právě jako gastarbajtři. Viz Künh-Memorandum. [Online]. Dostupné z: http://www.migration-online.de/data/khnmemorandum_1 .pdf [1.2.2018]; Rückblick: 30 Jahre Kühn-Memorandum. bpd.de [Online]. Dostupné z: http://www.bpb .de/gesellschaft/migration/newsletter/57143/rueckblick-30-jahre-kuehn-memorandum [1.2.2018]

11 HERBERT, U.: Geschichte der Ausländerpolitik in Deutschland. Saisonarbeiter, Zwangsarbeiter, Gastarbeiter, Flüchtlinge. Mnichov, 2001, s. 139-149, zde s. 149.

12 HINRICHS, J. - GIEBEL-FELTEN, E.: Die Entwicklung des Arbeitsmarktes 1962-2001. Sankt Augustin, 2002. Dostupné z: http://www.kas.de/wf/doc/kas_467-544-1-30.pdf?030610110803 [1.2.2018]. 
proto spolková vláda rozhodla stimulovat návrat cizinců a přijala tzv. zákon o pomoci k návratu (RückHG). ${ }^{13} \mathrm{Na}$ základě tohoto zákona měl být vytvořen tlak na ty cizince, kteří byli nezaměstnaní a pocházeli ze zemí, s nimiž SRN měla uzavřenou smlouvu o nabírání pracovníků (a které nebyly členskými zeměmi Evropských společenství), a to s cílem, aby Německo opustili. V praxi to umožňovalo podávat do 30. června 1984 žádosti o vycestování s tím, že tyto osoby měly nárok na jednorázovou platbu, označovanou jako „pomoc k návratu“ (ve výši 10500 DM za dospělou osobu a 1500 DM za dítě). Šlo zejména o občany z Jugoslávie, Portugalska, Španělska, Tuniska, Turecka a dalších zemí, kteří nebyli sezdáni s německým partnerem. ${ }^{14}$ Vycestovat takto mělo kolem 150000 osob. Po 30. červnu pozbyl tento zákon fakticky smyslu, protože už nezakládal další možnosti pro peněžitou sumu. Zákon však dodnes platí a na jeho základě mají ti, kdo zvažují návrat do země původu, garantovanou například možnost poradenství u Spolkové agentury pro práci. ${ }^{15}$

Návratovou politiku je z tohoto hlediska potřeba vnímat jako nedílnou součást integrace. Návraty se ostatně staly velmi diskutovaným problémem na počátku roku 2017 v souvislosti s přijetím zákona o lepším prosazení povinnosti vycestovat a restrikcemi, které tento zákon zavádí. ${ }^{16}$ Zákon byl hlasitě kritizován Radou uprchlíků (Flüchtlingsrat). ${ }^{17}$ Zavádí se jím např́íklad pružnější poskytování dat z mobilů uchazečů o azyl, „podezřelé“ osoby mohou nosit elektronické náramky a značně se úřadům ulehčuje hrozba vyhoštěním.

Jistou změnou $\mathrm{v}$ dosavadním spíše konzervativním a restriktivním př́stupu byly aktivity vlády Gerharda Schrödera, v nichž zasedala sociální demokracie a Zelení. Tato vláda přijala v roce 2000 zákon o státní příslušnosti s opcí, že v době od nabytí plnoletosti do 23. věku života mají osoby možnost přijmout bud' jedno z občanství (německé nebo to země jejich původu) anebo že do dovršení 21. roku života požádají o dvojí občanství. ${ }^{18}$ Tato nabídka však byla omezena zákonem o změně zákona o statním občanství z prosince 2014, který již přijala vláda Angely Merkelové: ${ }^{19}$ ty osoby, které v Německu žijí alespoň 8 let a které tam vychodily šest let školy nebo dokončily vzdělání, tuto možností volby již nemají a musí státní občanství přijmout. U posledních vlád s dominancí CDU/CSU vůbec pozorujeme snahu o zpřísnění zákona o státním občan-

13 SEIFERT, W.: Geschlossene Grenzen - offene Gesellschaften? Migrations- und Integrationsprozesse in westlichen Industrienationen. Frankfurt am Mein, 2000, s. 137.

14 FASSMANN, K.: Konzepte der (geographischen) Migrations- und Integrationsforschung. In FASSMANN, H. - DAHLVIK, J. (eds.): Migrations- und Integrationsfoschung-multidisziplinäre Perspektiven. Göttingen, 2001, s. 57-88, zde s. 60.

15 Viz Der Spiegel, 17. 9. 1984.

16 Bundesgesetzblatt, roč. 2017, část I, č. 52, z 28. července 2017. Dostupné z: https://www.bgbl.de/xa$\mathrm{ver} / \mathrm{bgbl} / \mathrm{start}$.xav?startbk=Bundesanzeiger_BGBl\&jumpTo=bgbl117s2780.pdf\#_bgbl_\%2F\%2F *\%5B\%40attr_id\%3D\%27bgbl117s2780.pdf\%27\%5D_1517483553882 [1.2.2018].

17 Flüchtlingsrat kritisiert „Gesetzentwurf zur besseren Durchsetzung der Ausreisepflicht“. Flüchtlingsrat Niedersachsen e.V. [Online]. Dostupné z: https://www.nds-fluerat.org/24643/pressemitteilungen/fluecht lingsrat-kritisiert-gesetzentwurf-zur-besseren-durchsetzung-der-ausreisepflicht/ [1.2.2018].

18 Staatsangehörigkeitsgesetz (StAG). Dostupné z: https://www.gesetze-im-internet.de/rustag /BJNR005830913.html [1.2.2018].

19 GERLOFF, V.: Kommentar aus Sicht der Anwaltschaft. In BRECHT-HEITZMANN, H. (ed.): Die Integration Geflüchteter als Herausforderung für das Sozialrecht. Münster, 2017, s. 147. 
ství. ${ }^{20}$ Zčásti je to způsobeno vlivem událostí, např́klad v důsledku tureckého referenda z minulého roku, na jehož základě vzrostl tlak na druhou generaci Turkủ, žijících v Německu, na to, aby se rozhodli pro jedno nebo druhé občanství. ${ }^{21} \mathrm{~A}$ tak dnes skutečně platí, že tzv. druhá generace Turků se musí mezi 18. až 23. věkem života rozhodnout pro jedno z občanství. Tím má zaniknout dosavadní praxe dvou pasů, kterou zažily ještě dvě předchozí generace, které v Německu žijí. Ostatně dnes to nejsou jen CDU/CSU, ale i například SPD, která vidí v dvojím občanství překážku v integraci a která podporuje tyto tlaky na generaci dnešních mladých Turků a ostatních cizinců z nečlenských zemí EU. To ostatně stálo i v programech těchto stran do uplynulých voleb do Bundestagu.

\section{NĚMECKO A OTEVŘENOST SMĚREM K PŘISTĚHOVALCŮM}

Pokud jsme zde hovořili o změně vnímání problematiky přistěhovalectví za vlád Gerharda Schrödera, pak další proměnou bylo i přijetí zákona o přistěhovalství, ${ }^{22}$ jemuž předcházely četné veřejné debaty, včetně např́íklad činnosti nezávislé komise „Přistěhovalectví“, vedené Ritou Süssmuthovou. ${ }^{23}$ Tento zákon byl novelizován hned v roce 2007, ovšem přináší další významnou změnu paradigmatu, která je opět dána tím, že postoje SPD a Zelených jsou dlouhodobě jiné, než je tomu u stran CDU/CSU. Ze zákona jednoznačně plyne, že Německo je zemí s přistěhovalci, že se k tomu přiznává a že se přiznává $\mathrm{i} k$ potřebě systematické politiky vůči přistěhovalcům. ${ }^{24}$ Základním pilířem této politiky je činnost Spolkového úřadu pro migraci a uprchlíky (BAMF), zejména jím organizované kurzy, které mají napomáhat integraci a které se realizují za součinnosti spolkové a zemské úrovně. ${ }^{25}$ Druhým pilírem jsou pak poradenské aktivity pro migranty, které financuje Spolková vláda, a paralelně s tím existují podobné aktivity také na úrovni spolkových zemí.

První vláda Angely Merkelové navázala na tyto aktivity v roce 2006 uspořádáním setkání zástupců těch institucí, které se podílejí na této politice. Výsledkem bylo přijetí Národního integračního plánu, na jehož základě se zavázala spolková a zemská úroveň, ale i obce a města k aktivní a udržitelné integrační politice. Tím se integrační politika pevně ukotvila na spolkové úrovni při zachování zásady víceúrovňového

20 TREBBE, J.: Akkulturation und Mediennutzung türkischer Jugendlicher in Deutschland. In BONFADELLI, H. - MOSER, H. (eds.): Medien und Migration. Europa als multikultur Raum? Wiesbaden, 2007, s. $183-208$, zde s. 199.

21 KÜNNECKE, A.: Türkei und EU. Perspektiven einer Partnerschaft nach dem gescheiterten Putsch. Noderstedt, 2017, s. 76.

22 Zuwanderungsgesetz. Dostupné z: http://dipbt.bundestag.de/doc/btd/15/004/1500420.pdf [1.2.2018].

23 SÜSSMUTH, R.: „Wir brauchen ein Zuwanderungsgesetz“. Mediendienst Integration [Online]. Dostupné z: https://mediendienst-integration.de/artikel/15-jahre-zuwanderungskommission-rita-suessmuth-ein wanderungsgesetz.html [1.2.2018].

24 BUTTERWEGGE, C. - HENTGES, G.: Einleitung. In BUTTERWEGGE, C. - HENTGES, G. (eds.): Zuwanderung im Zeichen der Globalisierung. Migration - Integrations- und Minderheitenpolitik. Opladen, 2000, s. 7.

25 SCHWEIGARD-KAHN, E.: Cultural Mainstreaming in der abschlussorientierten modularen Nachqualifizierung. In GRANATO, M. - MÜNK, D. (eds.): Migration als Chance. Ein Beitrag der bruflichen Bildung. Berlin, 2011, s. 113-142, zde s. 135. 
vládnutí. ${ }^{26}$ Následovalo přijetí dokumentu „Národní akční plán integrace“ v roce 2011, který již fakticky odpovídá tomu, co nazýváme „,vítací kulturou“ (Willkommenskultur). ${ }^{27}$ Angela Merkelová zde píše v úvodním slovu: „Mnoho z nich (cizinců) žije v naší zemi již po tři nebo čtyři generace, více jak polovina z nich má německé státní občanství. Zatímco celkový počet obyvatel země klesá, tak roste počet osob s migračním zázemím. Proto je integrace otázkou národního významu. “28 V tom samém roce pak došlo i ke schválení Zákona o zlepšení určení a uznání profesních kvalifikací, získaných v zahraničí, který též značně napomohl k tomu, aby se vylepšila životní situace cizinců, zejména jejich profesní vyhlídky.

Merkelová tím popsala významný demografický prvek Spolkové republiky Německo. Na něm nezměnila nic ani ta skutečnost, že počet osob, které přicházely do Německa, od roku 2010 de facto stagnovaly. To se však změnilo v letech 2015 a 2016 v důsledku události, kterou dnes běžně nazýváme jako „uprchlická krize“, čímž dáváme najevo jistý negativní kontext této události, a která zaskočila Evropu. Německo se zařadilo k zemím, které byly touto krizí postiženy vůbec nejvíce. Reakce společnosti přitom sahaly od „vítací kultury“, která se manifestovala i na ulicích různých německých měst v podobě lidské pomoci uprchlíkům, na druhou stranu ovšem vedla i k odmítání těchto migrantů a k posilování společenské polarizace a xenofobie. Zcela zaskočená vláda a samosprávy se postupně naučily s touto novou situací pracovat a stanovily restriktivní podmínky, které opět připomněly podstatu regulace německé migrace, která vždy cílila na integraci do pracovního trhu. Perspektiva dalšího života těchto osob v Německu je tak závislá na „práci a jazyku“, tedy na začlenění do práce a na znalosti německého jazyka - obecně na schopnosti se učit a začlenit do vzdělávacího systému (v případě mladých).

Ovšem původní integrační koncepty, založené na tlaku na začlenění se do pracovního trhu, se nejpozději od silvestrovské noci 2015 a událostí v Kolíně nad Rýnem začaly proměňovat. Objevila se debata o normativní a kulturní integraci, o níž se začalo hovořit v kontextu pojmu dominantní kultury (Leitkultur), který dosud však nijak do německé legislativy neprostoupil. Na druhou stranu to však má již dnes reálné dopady: nikde sice není stanoveno, co všechno by měli uprchlíci znát o německé společnosti, na druhou stranu se však hovoří o sdílení hodnot a představ německé společnosti. Zejména dosavadní kurzy pro migranty, které dosud nabízely převážně jazykovou výuku, by měly být obohaceny, a to konkrétně o ,zprostředkování znalostí právního systému, kultury a dějin Německa".29

26 Bundesministerium für Bildung und Forschung: Nationaler Aktionsplan Integration. Bilanz der Bundesmaßnahmen zum Dialogforum „Bildung, Ausbildung, Weiterbildung“. Dostupné z: https://www.bmbf.de /pub/Nationaler_Aktionsplan_Integration.pdf [1.2.2018].

27 Nationaler Aktionsplan Integration. Zusammenhalt stärken - Teilhabe verwirklichen. Dostupné z: https://www.bundesregierung.de/Content/DE/_Anlagen/IB/2012-01-31-nap-gesamt-barrierefrei.pdf?_blob $=$ publicationFile [1.2.2018].

28 Bundesregierung: Der Nationale Integrationsplan. Neue Wege - Neue Chancen. Berlin, 2011, s. 7. Dostupné z: http://www.kmk.org/fileadmin/Dateien/pdf/Bildung/AllgBildung/2007-10-18-nationaler-integrationsplan.pdf [2.2.2018].

29 WUTTKE, S.: Ehrenamtliche Helfer in der Flüchtlingsarbeit. Schulungskonzept für die Arbeit mit Menschen aus Syrien. Hamburg, 2017, s. 125. 
Tomuto trendu odpovídá i dosud poslední zákon, integrační zákon z roku 2016. Akcentovány jsou nadále zejména nástroje, které mají napomáhat $\mathrm{k}$ integraci do pracovního trhu, jako je větší nabídka integračních kurzů, vzdělávací aktivity a větší pomoc při zprostř̌edkovávání pracovních příležitostí. Ústřední heslo, které má ve zkratce vystihnout základní vlastnosti zákona, zní: „Fördern und Fordern“, což je jazyková hříčka, která znamená ,podporovat a vyžadovat“". Je to vůbec poprvé v historii Spolkové republiky Německo, co existuje zákon, který je právním základem pro integraci. Integrace se tak stává „nabídkou pro lidi, kteří k nám přijdou“, ale také očekáváním, ,že se naučí německý jazyk a že se budou ř́dit našimi zákony“ , ${ }^{30}$ vyslovila se při přijímání zákona Angela Merkelová. Zákon tedy vytváŕí podmínky pro to, aby se migranti učili jazyk a dále vzdělávali, rozšiřuje jejich nabídku, zprostředkovává jim bydlení tak, aby nebydleli ve vyloučených lokalitách či ubytovnách a pomáhá se zajištěním práce, za to však vyžaduje otevřenost těchto lidí vůči německé kultuře, právnímu pořádku a zvykům. Spolková ministryně práce a sociálních věcí Andrea Nahles se dokonce nechala slyšet, že jedny z prvních slov, které se cizinci učí, je „Bitte, Arbeit“, což je velkou výzvou a je to důležité i proto, že až 70 procent těchto osob je mladších než 30 let. ${ }^{31}$ Současné tlaky na akceptování právních a kulturních podmínek Spolkové republiky jsou reakcí na to, že řada německých cizinců není ochotna přijmout tyto německé podmínky, že neovládá jazyk a že se uchyluje ke kriminálním aktům.

\section{INTEGRAČNÍ KONCEPTY A VOLBY DO BUNDESTAGU 2017}

Současné integrační koncepty, at’ už pocházejí od jakékoli strany, jsou založeny na tom, aby z integrace profitovaly obě skupiny, tedy jak cizinci, tak i německá společnost. To však neznamená, že by na těchto konceptech panovala shoda. Naopak: každá strana si toto tvrzení vysvětluje jinak a akcentuje jiné požadavky.

Pokud začneme u CDU, tak ta je právě díky tomu, že její ministr stál i za vznikem nového integračního zákona, nositelkou onoho sousloví „podporovat a vyžadovat“ $s$ akcentem na křest’anské základy a na právní a hodnotovou orientaci země. V pozičním dokumentu strany se hovoří o tom, že integrace je závislá na otevřenosti těch, kteří žijí v Německu, a ta je závislá na připravenosti těch, kdo do země přicházejí, učit se novému způsobu života a poznat německou kulturu a německý jazyk. Doslova se zde praví: „Naše nabídka integrace se zaměřuje na ženy a muže s dobrou perspektivou, kteř́ vyžadují ochranu. Nezaměřuje se na osoby, které v Německu hledají lepší ekonomické podmínky. Těm bychom neměli dělat falešné naděje. Kdo zde nemá perspektivu, musí Německo opustit.“ $32 \mathrm{Na}$ co se před volbami CDU zaměřovala, a bylo to dáno zejména hrozbou ztráty voličstva ve prospěch Alternativy pro Německo, bylo ujištění o rovnosti

30 Die Bundesregierung: Grünes Licht im Bundesrat. Integrationsgesetz setzt auf Fördern und Fordern. Dostupné z: https://www.bundesregierung.de/Content/DE/Artikel/2016/05/2016-05-25-integrationsgesetz -beschlossen.html [2.2. 2018].

31 Fakten und Vorurteile. Woher kommen all die Flüchtlinge? NTV.de [Online]. Dostupné z: https://www .n-tv.de/politik/Woher-kommen-all-die-Fluechtlinge-article15691606.html [2.2. 2018].

32 CDU/CSU: Für ein Deutschland, in dem wir gut und gerne leben. Dostupné z: http://www.bundestagswahl -bw.de/wahlprogramm_cdu_btwahl2017.html [2.2.2018]. 
šancí jak pro migranty, tak i pro domácí obyvatelstvo, čímž měly být rozptýleny obavy části populace z toho, že jsou upozad’ováni na úkor cizinců.

Na rovnost šancí se zaměřuje ve svém programu také SPD. V programu stojí, že „nikdo nesmí mít horší šance jen kvůli svému migračnímu zázemí“. 33 V programu je sice migraci a integraci věnována samostatný kapitola, ovšem více se toho dočteme v kapitolách „Vzdělání a Práce“. V programu nalezneme jasné odsouzení pracovní migrace a nutnost spolupráce $v$ rámci EU, včetně zavedení přerozdělovacího mechanismu. Strana je vůči migrantům podstatně otevřenější. Hovoří se zde o nutnosti urychlit azylová řízení, efektivněji pracovat s cizinci, poskytovat jim kurzy a napomáhat jejich začleňování do společnosti. Program je tak výrazně otevřenější vůči cizincům, a jejich integraci, než je tomu u CDU.

U Zelených stojí za zmínku zejména požadavek na vytvoření sociálního bydlení, které si rodiny cizinců budou moci finančně dovolit. ${ }^{34}$ Strana se snaží dlouhodobě poukazovat na nutnost zesílit činnost ve školkách a školách. Velmi podobné programové priority pak pozorujeme také u Die Linke. $\mathrm{V}$ tomto jsou si tyto programy nejvíce podobné, oba můžeme označit za nejvíce otevřené směrem $k$ uprchlíkům a jejich začleňování do německé společnosti. ${ }^{35}$ Požadavek na zesílení vzdělávacích aktivit vznesla před volbami také FDP. Tato strana nemá sice $\mathrm{v}$ programu samostatnou kapitolu věnovanou problematice migrace a integrace, ovšem nalezneme tam požadavek okamžité účasti uprchlíků na výuce, a to i tehdy, když není jisté, zda budou mít pro život v Německu perspektivu, či nebudou. ${ }^{36}$ FDP uvádí v této souvislosti pojem „otevřená společnost“, což je liberální pojetí; CDU hovoří o „křest’anském pohledu na svět a o respektu k právnímu a hodnotovému systému země“. V programu této dlouhodobě nejsilnější politické strany se k tomu doslova píše, že otázka „bytí Němcem není otázkou původu nebo barvy pleti, ale otázkou postoje vůči naší zemi, našim lidem a našim hodnotám“.

Velmi specifický př́istup zastává AfD. Explicitně totiž zdůrazňuje, že integrace je záležitostí pouze migrantů, nikoli německé společnosti. Z programových dokumentů strany je od samého počátku zřejmý odmítavý postoj k osobám muslimské víry, když se např́klad hovoří o tom, že integrace neznamená, že ,se Německo přizpůsobí muslimům. Integrace znamená, že muslimové se přizpůsobí Německu“. ${ }^{37}$ Jinými slovy se zde cílí jednoznačně na to, aby muslimové, kteří chtěji žít v Německu, přijmuli německou „dominantní kulturu“. AfD vyžaduje tedy doslova asimilaci a ostře se vymezuje vůči multikulturalismu. Naopak se v programu píše o ochraně „německé kulturní identity“, o „kulturním boji mezi domácí kulturou a islámem“. Toto je velmi konzervativní př́stup k integraci, který je odleskem radikálně-politického př́stupu (tzv. völkisch, tedy národovecký) a který se zaměřuje na vytvoření v podstatě nepřátelské představy o muslimech. Cílem AfD je sice de facto asimilace, ve skutečnosti však je zdůrazňováno,

33 SPD: Es ist Zeit für mehr Gerechtigkeit. Dostupné z: http://www.bundestagswahl-bw.de/wahlprogramm spd_btwahl2017.html [2.2.2018].

34 Bündnis 90/Die Grünen: Bundestagswahlprogramm 2017+. Dostupné z: https://www.gruene.de/programm -2017.html [2.2.2018].

35 Die Linke: Wahlprogramm 2017. Dostupné z: https://www.die-linke.de/wahlen/wahlprogramm / [2.2.2018].

36 FDP: Wahlprogramm. Denken wir neu. Dostupné z: https://www.fdp.de/denkenwirneu [2.2.2018].

37 AfD: Wahlprogramm. Dostupné z: https://www.afd.de/wahlprogramm/ [2.2.2018]. 
že země není otevřena cizincům z islámských zemí, a zdůrazňuje se nutnost efektivně vyhoštovat tyto osoby. „Cílem zaškolení školou povinných uchazečů o azyl musí být to, abychom je dobře připravili na návrat do zemí původu a aby zde smysluplně strávili čas do doby, než budou navráceni.“"38

Jednotlivé integrační koncepty německých parlamentních stran se v několika aspektech protínají. U CDU, SPD, Zelených, Die Linke a FDP se akcentuje nutnost začlenění migrantů do pracovního trhu. To odpovídá tradici německých integračních konceptů. Tímto směrem chtějí tyto strany posilovat práci s migranty na různých úrovních. U Zelených a Die Linke se pak objevuje akcent na posilování práv žen a na zesílenou práci $\mathrm{s}$ nimi, ale i tlak na spolkovou úroveň, aby $\mathrm{v}$ integračních aktivitách podporovala obce a regiony. Obě strany se pak vyslovují i pro speciální psychosociální podporu migrantů. Jejich programy jsou v tomto ohledu podobné. Obě strany a s nimi i SPD pak usilují o zapojení občanského sektoru, zejména z oblasti kultury a sportu.

\section{ZÁVĚR}

Důsledky migrační krize postavily německé integrační koncepty před velké výzvy. Všechny politické strany byly přinuceny na to reagovat a vytvářet ucelené představy o tom, jak chtějí současné nadále nevyřešené problémy s uprchlíky řešit. Není pochyb o tom, že migrace představovala jedno z ústředních témat posledních voleb do Bundestagu a že voliče zajímalo, jaké integrační koncepty strany zastávají. Pozorujeme významnou proměnu v tom smyslu, že integrace je chápána všemi politickými stranami kromě AfD jako aktivita, na níž se musí odpovědně podílet jak sami migranti, tak cílová země a většinová společnost. $\mathrm{V}$ tom je stávající př́stup jiný a nový, protože až dosud byl kladen důraz hlavně na prístup cizinců. Tato oboustranná aktivita je však dnes již akcentována ve všech významných politických dokumentech, ostatně v tomto duchu je míněn i pojem „vítací kultura“ (Willkommenskultur).

V úvodu jsme si položili několik otázek, nikoli výzkumných, ale klíčových pro pochopení integrační politiky. Tou první bylo, koho chceme integrovat a koho ne. V tom dosud nepanuje shoda. Ví se, že země chce podporovat ty, kteří mají perspektivu se uplatnit (zejména na pracovním trhu), a jsou tedy pro zemi perspektivní. Kritéria pro to, co by cizinci měli splňovat, již existují, presto je zde ještě třeba řady zpřesnění. Na druhou stranu to, že ve vládě zůstane s největší pravděpodobností CDU/CSU, ukazuje na jisté trendy, které byly nastoleny již ministerstvem vnitra, které CDU ř́́dila. Ostatně pokud hovoř́me o kritériích, tak poměrně rozporuplné jsou dodnes i aktivity v otázce návratu cizinců. Ví se, že návratová politika se dosud nedaří, i když nelze říci, že by neexistovala. Otázka po tom, jakým způsobem a v jakých oblastech by integrace měla probíhat, je též sice poměrně jasná. Má totiž jít nadále o nutnost začlenění do pracovního trhu, k čemuž mají napomoci jazykové kurzy a různá pracovní i jiná školení. Německo v těchto věcech podniká mnohé kroky a pokouší se o zkvalitňování nabídky těchto vzdělávacích aktivit. Odpovídá to heslu z nového zákona o integraci cizinců -

38 Tamtéž. 
„podporovat a vyžadovat“. Jak konkrétně dospět k integraci a co má být na jejím konci, to jsou dosud spíše akademické debaty, na které je toto téma ještě př́liš živé a nové a legislativní nástroje, které vznikají, nefungují př́liš dlouho v praxi. Chce Německo migranty asimilovat, nebo integrovat? Toto byla klíčová otázka ve volbách směrem k Alternativě pro Německo. Tato strana využila značného znepokojení, které panovalo zejména v nových spolkových zemích. Zde ostatně tato strana obdržela v některých volbách do zemských parlamentů přses 20 procent hlasů. Koncept AfD je značně odmítavý zejména v otázce vstř́cnosti vůči uprchlíkům ze strany většinové populace. Integrace migrantů tak zůstává v Německu nadále velmi ožehavým tématem, na němž nepanuje shoda. A zůstává i velkou výzvou pro všechny další politické reprezentace.

Mgr. Lukáš Novotný, M.A., Dr. phil.

Filozofická fakulta Univerzity J. E. Purkyně v Ústí nad Labem

novotny.1@centrum.cz 